 \\ z Filologii Polskiej \\ i Słowiańskiej
}

Hanna Popowska-Taborska

(emerytowana profesor Instytutu Slawistyki PAN w Warszawie)

\author{
Nicole Dołowy-Rybińska \\ (Instytut Slawistyki PAN w Warszawie)
}

\section{Czy współcześnie powstający kaszubski język literacki oraz obecnie tworzony język neobretoński mogą stanowić przedmiot dociekań badaczy językowego obrazu świata?}

Wobec obserwowanego współcześnie rozkwitu badań nad językowym obrazem świata (JOS) oraz propagowanej przez zespół badawczy EUROJOS ${ }^{1}$ metody ankietowej przeprowadzanej wśród wybranej grupy studentów chciałybyśmy w niniejszym artykule podzielić się problemami, jakie w związku z tym nasuwają się etymologowi języka oraz badaczowi współczesnych zjawisk

${ }^{1}$ Dokładne informacje o celach, założeniach i metodologii projektu Językowo-kulturowy obraz świata Słowian i ich sąsiadów na tle porównawczym (EUROJOS) (b.d.) można znaleźć pod adresem internetowym: http://ispan.waw.pl/default/pl/projekty-naukowe/eurojos

This is an Open Access article distributed under the terms of the Creative Commons Attribution 3.0 PL License (creativecommons.org/licenses/by/3.0/pl/), which permits redistribution, commercial and non-commercial, provided that the article is properly cited. () The Author(s) 2015.

Publisher: Institute of Slavic Studies, PAS \& The Slavic Foundation

[Wydawca: Instytut Slawistyki PAN \& Fundacja Slawistyczna] 
kulturowych. Obserwowana obecnie sytuacja językowa na Kaszubach oraz w Bretanii powinna nas bowiem skłonić do pewnych dodatkowych refleksji metodologicznych.

Oto krótka charakterystyka sytuacji językowej panującej dzisiaj na Kaszubach i w Bretanii.

W drugiej połowie lat pięćdziesiątych i w początkach lat sześćdziesiątych ubiegłego stulecia w większości autochtonicznych wsi kaszubskich żyły jeszcze własnym, językowo zróżnicowanym życiem dialekty kaszubskie, którymi dzieci w wieku przedszkolnym i szkolnym biegle porozumiewały się ze swoimi dziadkami i rodzicami. Opracowany na podstawie zebranych w tym czasie materiałów Atlas językowy kaszubszczyzny i dialektów sąsiednich (AJK, 1964-1978), jak również opublikowany w zbliżonym czasie siedmiotomowy słownik Bernarda Sychty (Sychta, 1967-1976) ukazują archaiczność północnych i zachodnich krańców kaszubszczyzny oraz zaznaczające się na obszarze południowo-wschodnim liczne językowe zbieżności z sąsiednimi dialektami północnopolskimi. Stan podobny do utrwalonego na mapach AJK daje się również zauważyć w zgromadzonych o ponad pół wieku wcześniej materiałach Georga Wenkera (Popowska-Taborska \& Rzetelska-Feleszko, 2009)i Friedricha Lorentza (Lorentz, 1958-1962). O ile jednak w czasie poprzedzającym pierwszą wojnę światową mówić należy o narzuconej przez szkołę i wymogi administracyjne dwujęzyczności kaszubsko-niemieckiej, o tyle rosnące wpływy polszczyzny w okresie późniejszym spowodowały wzrastającą tu z biegiem czasu dwujęzyczność kaszubsko-polską i - podobnie jak w innych rejonach Polski - rozpoczęly proces zanikania dialektów. W tym samym czasie przybrały na sile mające już długą tradycję próby stworzenia kaszubskiego języka literackiego (Breza, 1997, ss. 247-256, 2001; Treder, 2005, 2009, ss. 33-42), co bez wątpienia wiąże się z doniosłym dla społeczności kaszubskiej faktem nadania kaszubszczyźnie przez Sejm Rzeczypospolitej Polskiej w roku 2005 statusu języka regionalnego. Powstająca obecnie forma języka kaszubskiego w zamierzeniu jego twórców zająć ma miejsce silnie zróżnicowanych dialektów, których znajomość $\mathrm{w}$ młodszym pokoleniu zanika w niepokojącym tempie. Jesteśmy dziś świadkami wielu przemyślanych poczynań kaszubskiej inteligencji, która pragnie tę nową wersję obdarzyć jak najszybciej cechami współczesnego języka literackiego i wprowadzić w życie w wersji zarówno pisanej, jak i mówionej. Nowy twór językowy, przystosowywany do funkcjonowania na wszystkich płaszczyznach współczesnego życia, odznacza się już jednak całym szeregiem specyficznych cech. 
Materiał językowy do powstającego języka literackiego czerpany jest głównie z najbardziej archaicznych kaszubskich dialektów północnych i północno-zachodnich i dostosowywany do swych nowych funkcji w nieustannej opozycji do polskiego języka literackiego. W formowanym nowym kaszubskim języku literackim ożywają więc słowiańskie archaizmy, których polszczyzna zaniechała bądź które nigdy w niej nie funkcjonowały; aprobowane są też nieznane polszczyźnie zapożyczenia z dolnoniemieckiego; powstają również liczne neologizmy. Wskrzeszanym obecnie wyrazom często nadawane są nowe znaczenia, których wyrazy te nie miały (i mieć nie mogły) w dawnych dialektach kaszubskich.

Mimo niewątpliwego faktu, że część społeczności kaszubskiej jest żywo zainteresowana wprowadzeniem w życie nowej wersji języka kaszubskiego, nie przestaje on jednak być językiem zagrożonym. Posługiwanie się nową formą języka nie ma bowiem motywacji praktycznych, lecz wyłącznie kulturowe i emocjonalne (w niektórych wypadkach również polityczne), a dobra znajomość polszczyzny jest nadal niezbędna do normalnego życia ekonomicznego i społecznego społeczności kaszubskiej. Jest to ponadto język nowy dla wszystkich jego użytkowników - zarówno dla tych, którzy uczą się go w szkołach i na lektoratach, jak i dla tych, którzy znajomość kaszubszczyzny wynieśli z domu, obecnie zaś konstatują znaczną odmienność rodzimego dialektu od języka prezentowanego im we współcześnie powstających tekstach.

Analizując współczesną kaszubszczyznę, winniśmy więc nieustannie mieć na uwadze jej obecne rozwarstwienie zgodnie $\mathrm{z}$ dawnym obrazem zakodowanym w silnie zróżnicowanych dialektach oraz jej nową, kształtującą się postać, utrwalaną obecnie na różne sposoby, której każdy Kaszuba powinien się nauczyć, ale która długo jeszcze nie będzie ukształtowana i wdrożona w sposób ostateczny.

Stopień wzajemnego oddziaływania na siebie obu tych warstw (tej autentycznej, bardzo silnie zróżnicowanej i tej nowo powstającej, ujmowanej w coraz bardziej szczegółowe normy) bywa w młodszym pokoleniu niewątpliwie różny, uzależniony od znajomości gwary wyniesionej z rodzinnego domu oraz od stopnia wyuczenia się nowej literackiej postaci języka. Do tego dodać należy niebagatelny w tego typu rozważaniach fakt dwujęzyczności dzisiejszych Kaszubów, którzy wszyscy (może z wyjątkiem najstarszego pokolenia) posługują się polskim językiem literackim na równi ze swoimi rówieśnikami z innych obszarów Polski (Popowska-Taborska, 2012, s. 243; por. w związku z tym również Popowska-Taborska, 2010, ss. 53-71, 2013, ss. 143-149).

Według statystyk językiem bretońskim posługuje się jeszcze około 200 tysięcy osób, jednak 70\% z nich ma powyżej 60 lat (Broudic, 2009). 
Transmisja międzypokoleniowa bretońskiego została niemal całkowicie przerwana w połowie XX wieku, kiedy użytkowników bretońskiego było jeszcze 1,1 miliona. Przyczyn tak gwałtownego upadku bretońskiego jest wiele: polityka językowa Francji, nastawiona na zwalczanie języków mniejszościowych w życiu zarówno publicznym, jak i prywatnym; zmiana stylu życia (z kultury rolniczo-rybackiej na coraz bardziej miejską); pojawienie się wyłącznie francuskojęzycznych mediów masowych; silna migracja Bretończyków w poszukiwaniu pracy (co musiało się wiązać z przechodzeniem na język dominujący); osiedlanie się Francuzów w Dolnej Bretanii. Równie istotne okazały się przyczyny psychologiczne masowego porzucania języka bretońskiego: w zbiorowej świadomości język ten był upokarzany, kojarzony $\mathrm{z}$ brudem, prostactwem, analfabetyzmem, niemożnością dostąpienia awansu społecznego (Dołowy-Rybińska, 2011, ss. 92-104). Rodzice chcieli dla swoich dzieci lepszej przyszłości, więc zaczęli wychowywać je w języku francuskim. Od połowy XX wieku bretoński używany był w życiu prywatnym jedynie w zamkniętych grupach wiekowych i towarzyskich.

Prawdopodobnie sytuacja taka doprowadziłaby do całkowitego zepchnięcia języka bretońskiego na margines, gdyby nie wydarzenia, które miały miejsce w latach 70. XX wieku. Odrodzenie etniczne i językowe doprowadziło do stopniowej rewaloryzacji kultury bretońskiej i jej języka. Coraz więcej osób zaczęło aktywnie włączać się w działania na rzecz kultury bretońskiej, uczestniczyć w bretońskim ruchu zarówno politycznym, jak i kulturalnym. W Bretanii powstawać zaczęły pierwsze immersyjne szkoły Diwan (w których nauka odbywa się wyłącznie po bretońsku) ${ }^{2}$, szkoły dwujęzyczne oraz inne bretońskie instytucje, a na kulturę bretońską przekazywane były coraz większe dotacje. Obecnie kilkadziesiąt tysięcy osób można nazwać néo-bretonnants, czyli nowymi użytkownikami języka bretońskiego, którzy znajomości bretońskiego nie wynieśli z domu, ale nauczyli się go na kursach i/lub w szkołach. Używany przez nich język znacznie jednak różni się od dialektalnego bretońskiego.

Odradzający się w latach 70 . XX wieku, standaryzowany w dużej mierze w latach 90. wraz z rozwojem szkolnictwa bretońskojęzycznego i powstaniem

2 Pierwsze przedszkole założono w 1977 roku, pierwszą szkołę podstawową - w 1980, pierwsze gimnazjum - w 1988, liceum zaś - w 1994 roku. Obecnie sieć szkół Diwan jest rozbudowana: funkcjonuje 41 szkół przedszkolnych i podstawowych, sześć gimnazjalnych i jedno liceum. 
instytucji sprawującej nad tym pieczę - Publicznego Biura Języka Bretońskiego (Office Public de la langue bretonne / Ofis Publik Ar Brezhoneg) - język bretoński uległ znacznemu przekształceniu. Można powiedzieć, że dziś bretoński istnieje w dwóch postaciach: bretońskiego używanego na wsiach Dolnej Bretanii przez starsze pokolenie oraz „nowego bretońskiego" (néo-breton), którego uczą się młodzi Bretończycy w szkołach (Hornsby, 2005, s. 194). Dla badań nad językowym obrazem świata bardzo istotny jest fakt, że między starszym pokoleniem osób bretońskojęzycznych a néo-bretonnants nie ma prawie żadnych kontaktów. Obie grupy deklarują, że nie rozumieją się nawzajem, że ich język odnosi się do zupełnie innej sytuacji komunikacyjnej, a czasem nawet, że kontakty takie byłyby trudne, jeśli nie bezcelowe.

Mimo istnienia bretońskiego języka literackiego bretoński starszego pokolenia jest używany prawie wyłącznie w formie oralnej i odznacza się silnym zdialektyzowaniem. Oprócz czterech podstawowych dialektów o wyraźnych, opisanych przez językoznawców cechach odróżniających funkcjonowało wiele subdialektów, często nieznacznie różniących się w każdej niemal wiosce. Dialektalny bretoński był więc nierozerwalnie związany z życiem codziennym, wykonywaną pracą, naturą, obyczajami, religią. Odzwierciedlał lokalną tożsamość jego użytkowników: posługiwanie się daną odmianą dialektu bretońskiego odróżniało jedną wspólnotę tery torialną od drugiej. Ze względu na liczne kontakty między kulturą francuską i bretońską, dialektalny bretoński wykazuje wiele zapożyczeń $\mathrm{z}$ języka francuskiego $\mathrm{w}$ warstwie leksykalnej. $\mathrm{Z}$ francuskiego pochodzą nowe słowa, określenia, zwroty. Natomiast systemy gramatyczne tych dwóch języków pozostają szczelnie oddzielone: w syntaksie bretońskiego nie ma wpływów francuskich (Jones, 1998, s. 321).

Tymczasem néo-breton jest językiem standardowym, nauczanym w szkołach, używanym w mediach i w życiu publicznym. Został on stworzony i funkcjonuje jako język wspólny dla wszystkich Bretończyków - niezależnie od miejsca urodzenia czy od dialektu używanego przez starsze pokolenia ma być językiem łączącym wszystkich bretońskojęzycznych mieszkańców Bretanii oraz tych, którzy chcą stać się bretońskojęzyczni.

Nowy bretoński został stworzony na podstawie istniejących dialektów, których poszczególne cechy zostały wyselekcjonowane i zmieszane. Zmianie uległ m.in. szyk zdania, uproszczone zostały mutacje (zmiany inicjalnej głoski), ujednolicono akcent itd. Stworzono liczne neologizmy, odpowiadające nowej rzeczywistości. Celem reformy języka bretońskiego było również oczyszczenie go z naleciałości języka francuskiego, dlatego też wiele bretońskich słów 
zastąpiono ich „celtyckimi” odpowiednikami (stworzonymi zwłaszcza na podstawie języka walijskiego), np. néo-breton prof, bretońskie dialektalne prezen, francuskie présent 'prezent', czy néo-breton gwalc'herez, bretońskie dialektalne machinalave, francuskie machine à laver 'pralka'.

Jednak nie tylko zmiana słownictwa bretońskiego sprawia, że badanie językowego obrazu świata na podstawie standardowego języka bretońskiego jest trudne lub niemożliwe. Przede wszystkim język ten nie jest dla nikogo językiem pierwszym. Młodzi ludzie uczą się go w szkole, często od osób, które same się tego języka nauczyły. A więc przerwana została ciągłość nie tylko transmisji języka, lecz także związanego $\mathrm{z}$ nim i zawartego w nim obrazu świata.

Przypomnijmy, że według profesora Jerzego Bartmińskiego zadaniem badacza językowego obrazu świata jest wydobycie zawartej w języku interpretacji rzeczywistości, „którą można ująć w postaci zespołu sądów o świecie. Mogą to być sądy utrwalone w samym języku, w jego formach gramatycznych, słownictwie, kliszowanych pojęciach (np. przysłów), bądź też przez formy i teksty implikowane" (Bartmiński, 1999, s. 104).

W innym miejscu Bartmiński stwierdza, że

rekonstrukcja [językowego obrazu świata] opiera się na szerokiej bazie materiałowej, odwołuje się do semantycznej analizy kategorii gramatycznych i słownictwa, do łączliwości leksykalnej (stałej i okazjonalnej) i metafor, do struktury logiczno-semantycznej i treści tekstów zarówno kliszowanych (tj. różnych gatunków folkloru: przysłów, zagadek, pieśni, bajek itd.) jak też kreowanych (w ich warstwie presuponowanej, implikowanej). Przydatne do rekonstrukcji JOS są teksty wywołane, tj. odpowiedzi na pytania o rozumienie słów przez ich użytkowników oraz opisy rytualnych zachowań i wierzeń dotyczących nazywanych przedmiotów (Bartmiński, 2013, s. 235).

Zadać więc należy pytanie, czy opisany przez nas wyżej współcześnie powstający kaszubski język literacki oraz tworzony obecnie język nowobretoński stanowią właściwy przedmiot badań dla badaczy JOS, skoro:

1. są dla wszystkich użytkowników nowymi językami, w różnym stopniu i na różny sposób wyuczonymi wtórnie;

2. funkcjonuje w nich wiele neologizmów, stworzonych przez elity mniejszości;

3. zarówno kaszubski, jak i bretoński poddawane są procesowi „puryfikacji”, których celem jest sztuczne/celowe oczyszczenie ich z cech upodabniających do języka dominującego (polskiego i francuskiego). Nowe słowa tworzone są na podstawie innych języków (słowiańskich dla kaszubskiego, celtyckich dla bretońskiego); 
4. ani nowy kaszubski, ani neobretoński powszechnie nie funkcjonują w codziennej komunikacji. Używane są natomiast w sferach, w których ani dialektalny kaszubski, ani bretoński nie funkcjonowały: w szkole, w mediach, urzędach.

Jeśli zaś chodzi o propagowaną przez JOS metodę badań ankietowych, to panująca obecnie na Kaszubach dwujęzyczność kaszubsko-polska każe spodziewać się, że stosowana przez badaczy JOS metoda ankietowa nie przyniesie jednoznacznych dla kaszubszczyzny wyników. Istniejąca między polszczyzną i kaszubszczyzną więź bliskiego językowego pokrewieństwa, pogłębiana przez odwieczne bezpośrednie sąsiedztwo obu tych języków, sprawiła, że wiele wyrazów różniących kaszubszczyznę od polszczyzny zachowało się szczątkowo wyłącznie na północnych i zachodnich krańcach Kaszub. Wyrazy te, wprowadzane obecnie do kaszubskiego języka literackiego, nie były znane większości kaszubskich dialektów. Z jakiego więc obszaru Kaszub i w jakim wieku należy $\mathrm{w}$ takim razie brać respondentów celem przeprowadzenia ankiety JOS?

$\mathrm{Z}$ podobnym problemem mamy do czynienia w przypadku języka bretońskiego. Od doboru grupy respondentów zależałyby wyniki ankiety JOS. Prawdopodobnie inny językowy obraz świata bretońskiego otrzymalibyśmy w wyniku ankietowania studentów „bretonistyki” na Uniwersytecie Rennes II, a zupełnie inny wskutek przeprowadzenia analogicznej ankiety wśród starszego pokolenia osób bretońskojęzycznych. Można też postawić hipotezę, że ankieta JOS przeprowadzona wśród studentów bardziej odpowiadałaby wynikom takiej ankiety dla języka francuskiego niż analogicznej dla języka bretońskiego starych użytkowników dialektalnych odmian bretońskiego.

Bibliografia

Bartmiński, J. (1999). Punkt widzenia, perspektywa, językowy obraz świata. W J. Bartmiński (Red.), Językowy obraz świata (ss. 103-120). Lublin: Wydawnictwo Uniwersytetu Marii Curie-Skłodowskiej.

Bartmiński, J. (2013). Rola etymologii w rekonstrukcji językowego obrazu świata. LingVaria, 8(16), 233-245. http://doi.org/10.12797/LV.08.2013.16.15

Breza, E. (1997). Kształtowanie się kaszubskiego języka literackiego. W J. Zieniukowa (Red.), Obraz językowy słowiańskiego Pomorza i Łuzyc: pogranicza i kontakty językowe (ss. 247-257). Warszawa: Slawistyczny Ośrodek Wydawniczy. 
H. Popowska-Taborska, N. Dołowy-Rybińska Czy wspótcześnie powstający kaszubski język...

Breza, E. (Red.). (2001). Kaszubszczyzna. Kaszëbizna. Opole: Uniwersytet Opolski, Instytut Filologii Polskiej.

Broudic, F. (2009). Parler breton au XXIe siècle: le nouveau sondage de TMO-Réions. Brest: Emgleo Breiz.

Dołowy-Rybińska, N. (2011). Języki i kultury mniejszościowe w Europie: Bretończycy, Łużyczanie, Kaszubi. Warszawa: Wydawnictwa Uniwersytetu Warszawskiego.

Hornsby, M. (2005). Néo-breton and questions of authenticity. Estudios de Sociolinguistica, $6(2), 191-218$.

Językowo-kulturowy obraz świata Słowian i ich sąsiadów na tle porównawczym (EUROJOS). (b.d.). Pobrano 20 lutego $2014 \mathrm{z}$ http://ispan.waw.pl/default/pl/projekty-naukowe/eurojos

Jones, M. (1998). Language obsolescence and revitalization: Linguistic change in two sociolinguistic contrasting Welsh communities. Oxford: Clarendon Press.

Lorentz, F. (1958-1962). Gramatyka pomorska (T. 1-3). Wrocław: Zakład Narodowy imienia Ossolińskich.

Popowska-Taborska, H. \& Rzetelska-Feleszko, E. (2009). Dialekty kaszubskie w świetle dziewiętnastowiecznych materiałów archiwalnych: prezentacja i opracowanie kaszubskich materiałów językowych zebranych przez Georga Wenkera w latach 1879-1887. Warszawa: Instytut Slawistyki Polskiej Akademii Nauk, Fundacja Slawistyczna.

Popowska-Taborska, H. (2010). W poszukiwaniu językowego obrazu świata: dom, praca, wolność, a także honor i Europa w kaszubskich dialektach i w powstającym kaszubskim języku literackim. Etnolingwistyka, 22, 53-71.

Popowska-Taborska, H. (2012). W poszukiwaniu językowego obrazu świata: o zawiłości dziejów pojęć i wyrazów: dom, wolność, honor i Europa na współczesnych Kaszubach). W M. Abramowicz \& I. Bielińska-Gardziel (Red.), Wartości w językowo-kulturowym obrazie świata Słowian i ich sq̨siadów (ss. 242-249). Lublin: Wydawnictwo Uniwersytetu Marii Curie-Skłodowskiej.

Popowska-Taborska, H. (2013). Rola zapożyczeń w procesie kształtowania się językowego obrazu świata. W A. V. Gura, O. V. Belova \& E. L. Berezovič (Red.), Slavica Svetlanica: IAzyk i kartina mira: k iubileiu Svetlany Mikhaĭlovny Tolstoŭ (ss. 143-149). Moskva: Indrik.

Sychta, B. (1967-1976). Słownik gwar kaszubskich na tle kultury ludowej (T. 1-7). Wrocław: Zakład Narodowy imienia Ossolińskich.

Treder, J. (2005). Historia kaszubszczyzny literackiej. Gdańsk: Wydawnictwo Uniwersytetu Gdańskiego.

Treder, J. (2009). Spòdlowô wiédza ò kaszëbizńe. Gdańsk: Oficyna Czec.

Zespół Zakładu Słowianoznawstwa PAN. (1964-1978). Atlas językowy kaszubszczyzny i dialektów sąsiednich [AJK]. (Pod kier. Z. Stiebera - T. wstępny-6, pod kier. H. Popowskiej-Taborskiej - T. 7-15). Wrocław: Zakład Narodowy imienia Ossolińskich. 


\section{Can the presently created Kashubian literary language and the currently formed new Breton language be objects of consideration for researchers of the linguistic picture of the world?}

\section{Summary}

The influence of the Polish language in conjunction with education and the mass media have brought about in the second half of the $20^{\text {th }}$ century a growth of Polish-Kashubian bilingualism and a decline of Kashubian dialects. Simultaneously, work on the creation and promotion of the literary Kashubian language has begun. The standard Kashubian language is new to all users as is the new Breton language standardized in the last decades of the $20^{\text {th }}$ century. Intergenerational transmission of the Breton language was severed after WWII. The ethnic revival of the 1970s led to the revalorization of the Breton culture and language, taught since then in a number of schools and at adult courses. Normalized Kashubian and Breton languages are full of neologisms. But at the same time they have also been considerably purified of those traits which make them similar to the respective dominant language (Polish and French). Furthermore, the range of use to which these minority languages are put is very different from one user to another. All these specifics result in the near impossibility of researching the linguistic picture of the world of contemporary normalized minority languages. 


\section{Czy współcześnie powstający kaszubski język literacki oraz obecnie tworzony język neobretoński mogą stanowić przedmiot dociekań badaczy językowego obrazu świata?}

\section{Streszczenie}

Wpływ polszczyzny związany ze szkołą i mediami masowymi spowodował wzrost w drugiej połowie XX wieku dwujęzyczności kaszubsko-polskiej i zanikanie dialektów kaszubskich. Jednocześnie rozpoczęły się prace nad stworzeniem i upowszechnieniem kaszubskiego języka literackiego. Standardowy język kaszubski jest nowy dla wszystkich użytkowników, podobnie jak standaryzowany w drugiej połowie XX wieku język bretoński. Międzypokoleniowa transmisja bretońskiego została przerwana w połowie XX wieku. Odrodzenie etniczne lat 70. XX wieku doprowadziło do rewaloryzacji kultury i języka bretońskiego, którego dzieci zaczęły się uczyć w szkołach, a dorośli - na kursach. Znormalizowane języki kaszubski i bretoński pełne są neologizmów, podlegają również procesom puryfikacji mającym oczyścić je z cech upodobniających do języka dominującego (polskiego i francuskiego). Zakres posługiwania się nimi u poszczególnych ich użytkowników jest silnie zróżnicowany. Wszystkie te fakty sprawiają, że badanie językowego obrazu świata normalizowanych obecnie języków mniejszościowych nie wydaje się możliwe.

Keywords: Kashubian language; Breton language; linguistic picture of the world; language standardization; minority languages

Słowa kluczowe: język kaszubski; język bretoński; językowy obraz świata; standaryzacja języka; języki mniejszościowe

(1) Hanna Popowska-Taborska, Professor emerita, Institute of Slavic Studies of the Polish Academy of Sciences, Warsaw

(2) Nicole Dołowy-Rybińska, Institute of Slavic Studies of the Polish Academy of Sciences, Warsaw

Correspondence: nicoledolowy@gmail.com

This work was supported by a core funding for statutory activities from the Polish Ministry of Science and Higher Education.

Authors contribution: both authors are responsible for the article idea and construction; H. P.-T. is responsible for the Kashubian part and N. D.-R. is responsible for the Breton part. The article's conclusion is shared. Both authors participated in drafting the manuscript.

Competing interests: the authors declare that they have no competing interests. 